\title{
An audit of out of hours MRI scanning at a tertiary care referral hospital
}

\author{
S Alnafisee*, A O'Hare, J Thornton, P Brennan, S Looby \\ From International Conference for Healthcare and Medical Students (ICHAMS) 2013 \\ Dublin, Ireland. 11-12 October 2013
}

\section{Introduction}

The aim of this audit was to record the numbers of MRI scans performed out of hours or on-call in a busy tertiary care referral hospital. As this service continues to increase, we look at the trends and patterns in referrer pathways, the clinical indications for these studies, the types of studies performed, the results of these studies and the impact on patient management.

\section{Materials and methods}

We retrospectively viewed the on-call MRI logbooks at Beaumont hospital and recorded all scans done this past decade. Regarding each study, the following major parameters were recorded; indication for study, requesting service, type of MRI performed, the result of each study and the impact on patient management.

\section{Results}

A total of 1332 on-call MRI scans were performed on-call this past decade (2003-2012). The largest increase in scan numbers was from 2010-2011 and 2011-2012. The most frequent scan was that of the spine, followed by the brain. Fifty four percent of scans were positive, with a significant result altering patient management. The largest cohort of scans was referred by the neurosurgery service.

\section{Conclusion}

There has been an exponential increase in out of hours MRI scanning over the past decade. This is an expensive service requiring several on-call staff. Despite the addition of a second MRI magnet at our hospital, this demand has continued to increase. For future planning of services, increasing MRI availability will be necessary, possibly in the form of an extended working day and/or in acquiring additional MRI magnets.

Department of Neuroraudiology, Beaumont Hospital, Dublin 9, Ireland
Published: 14 January 2015

doi:10.1186/1753-6561-9-S1-A53

Cite this article as: Alnafisee et al.: An audit of out of hours MRI scanning at a tertiary care referral hospital. BMC Proceedings 2015 9(Suppl 1):A53.
Submit your next manuscript to BioMed Central and take full advantage of:

- Convenient online submission

- Thorough peer review

- No space constraints or color figure charges

- Immediate publication on acceptance

- Inclusion in PubMed, CAS, Scopus and Google Scholar

- Research which is freely available for redistribution
() Biomed Central 